\title{
Cell volume regulation in epithelial physiology and cancer
}

\section{Stine F. Pedersen, Else K. Hoffmann and Ivana Novak*}

Department of Biology, University of Copenhagen, Copenhagen, Denmark

\section{Edited by:}

Annarosa Arcangeli, University of

Florence, Italy

\section{Reviewed by:}

Jorge Arreola, Universidad

Autónoma de San Luis Potosi,

Mexico

Enrique Hernandez-Lemus, National Institute of Genomic Medicine,

Mexico

\section{*Correspondence:}

Ivana Novak, Molecular and Integrative Physiology, Department of Biology, University of

Copenhagen, August Krogh

Building, Universitetsparken 13,

Copenhagen $\varnothing$, DK 2100, Denmark

e-mail: inovak@bio.ku.dk
The physiological function of epithelia is transport of ions, nutrients, and fluid either in secretory or absorptive direction. All of these processes are closely related to cell volume changes, which are thus an integrated part of epithelial function. Transepithelial transport and cell volume regulation both rely on the spatially and temporally coordinated function of ion channels and transporters. In healthy epithelia, specific ion channels/transporters localize to the luminal and basolateral membranes, contributing to functional epithelial polarity. In pathophysiological processes such as cancer, transepithelial and cell volume regulatory ion transport are dys-regulated. Furthermore, epithelial architecture and coordinated ion transport function are lost, cell survival/death balance is altered, and new interactions with the stroma arise, all contributing to drug resistance. Since altered expression of ion transporters and channels is now recognized as one of the hallmarks of cancer, it is timely to consider this especially for epithelia. Epithelial cells are highly proliferative and epithelial cancers, carcinomas, account for about $90 \%$ of all cancers. In this review we will focus on ion transporters and channels with key physiological functions in epithelia and known roles in the development of cancer in these tissues. Their roles in cell survival, cell cycle progression, and development of drug resistance in epithelial cancers will be discussed.

\footnotetext{
Keywords: $\mathrm{K}^{+}$channels, $\mathrm{Cl}^{-}$channels, tumour microenvironment, drug resistance, pancreatic cancer, breast cancer, stroma, secretion
}

\section{INTRODUCTION}

Broadly speaking, epithelia are organized into sheets, tubes, or glandular structures, and perform complex tasks of transporting ions, organic molecules, and water for which specific ion channels/transporters are required. The majority of cancers are of epithelial origin, and the altered ion channel/transporter expression, which is emerging as one of the hallmarks of cancer in general (Prevarskaya et al., 2010; Lehen'kyi et al., 2011), is also a marked characteristic of epithelial cancers. In this review we will first outline the ion transport mechanisms operating in epithelia under physiological conditions of ion/fluid transport and cell volume regulation. Next, we will review and

Abbreviations: ABC, ATP-binding cassette; AVD, apoptotic volume decrease; $\alpha$ SMA, $\alpha$-smooth muscle actin; BK, big conductance $\mathrm{K}^{+}$channel, also named KCal.1 and maxi- $\mathrm{K}^{+}$; CA, carbonic anhydrase; CAFs, cancer associated fibroblasts; $\left[\mathrm{Ca}^{2+}\right]_{I}$, intracellular $\mathrm{Ca}^{2+}$ activity; CFTR, the cystic fibrosis transmembrane conductace regulator; EATC's, Ehrlich ascites tumour cells; ECM, extracellular matrix; EGF, epidermal growth factor; ELA, Ehrlich Lettre ascites carcinoma; EMT, epithelial-to-mesenchymal transition; ERK1/2, extracellular signal regulated kinase; HICCS, hypertonicity-induced cation channels; HIF1 $\alpha$, hypoxia-inducible factor- $1 \alpha$; IK, intermediate conductance $\mathrm{K}^{+}$channel, also named KCa3.1; MAPK, mitogen-activated protein kinase; MCT, monocarboxylate transporters; MDR, multi drug resistance; $\mathrm{NBC}, \mathrm{Na}^{+}-\mathrm{HCO}_{3}^{-}$transporter; $\mathrm{NHE}, \mathrm{Na}^{+} / \mathrm{H}^{+}$exchanger NKCCl, $\mathrm{Na}^{+}-\mathrm{K}^{+}-2 \mathrm{Cl}^{-}$cotransporter; VRAC, volume regulated $\mathrm{Cl}^{-}$channel; OSR1, oxidative stress responsive kinase; $\mathrm{pH}_{\mathrm{i}}$, intracellular $\mathrm{pH} ; \mathrm{pH}_{\mathrm{e}}$, extracellular $\mathrm{pH}$; PCD, programmed cell death; PSCs, pancreatic stellate cells; PDAC, pancreatic ductal adenocarcinoma; RVI, regulatory volume increase; RTK, receptor tyrosine kinase; RVD, regulatory volume decrease; SOCE, store-operated calcium entry; SPAK, SPS-related proline/alanine-rich kinase; TME, tumor microenvironment; VDAC-1, mitochondrial voltage-dependent anion channel; TRP, transient receptor potential channels; VEGF, vascular endothelial growth factor; WNK, with no lysine kinase; ZO-1, tight junction protein. critically discuss how dys-regulation of cell volume or given ion transporters can lead to loss of epithelial architecture, altered cell survival, tumor progression, and drug resistance. The focus will be on cancers of secretory epithelia, primarily pancreatic ductal adenocarcinoma (PDAC) and mammary cancer.

\section{PHYSIOLOGY OF EPITHELIAL TRANSPORT AND ROLE OF CELL VOLUME}

Animal cells are subjected to transmembrane osmotic gradients in a number of physiologically relevant conditions, including: (i) ion/nutrient transport followed by osmotically obliged water movement; (ii) metabolic activity generating or requiring osmotically active substances; or (iii) altered extracellular osmolarity of the environment [see Hoffmann et al. (2009)]. Epithelial cells are of special interest because they carry out net transport of electrolytes, nutrients, and water in the secretory or reabsorptive direction, conditions in which cell volume regulation is a particular challenge. A question that has raised substantial interest in the field is how well cell volume regulation is achieved under these conditions, and to what extent cell volume changes contribute to the regulation of secretion/absorption. Furthermore, little is known about what happens to cell volume regulation if the normal vectorial epithelial transport is prevented or dysregulated. It is well documented that several pathophysiological conditions, including altered $\mathrm{Na}^{+} / \mathrm{K}^{+}$balance and acid/base disturbances caused by renal disease, or cardiac or brain ischemia, are associated with dys-regulation of cell volume regulatory transporters, and that the associated cell volume disturbance 
contributes importantly to the pathology of these conditions (for reviews, see Lang, 2007; Hoffmann et al., 2009; Pedersen et al., 2011).

In absorptive epithelia such as the renal tubules, small intestine, gallbladder, and skin, the most common mechanism of transepithelial transport involves luminal channels and transporters that utilize the plasma membrane $\mathrm{Na}^{+}$gradient for salt and nutrient transport, which would tend to swell the cells. Isosmotic transport and recovery of cell volume under these conditions is likely achieved through activation of basolateral stretch-activated $\mathrm{K}^{+}$channels, volume regulated $\mathrm{Cl}^{-}$channels (VRAC), and increased activity of the $\mathrm{Na}^{+} / \mathrm{K}^{+}$pump, followed by exit of ions/nutrients and osmotically obliged water across the basolateral membrane (Lang et al., 1998; Vanoye and Reuss, 1999; Schultz and Dubinsky, 2001; Hoffmann et al., 2009; Bachmann et al., 2011).

Here, we will focus on secretory epithelia such as pancreas, salivary glands, colorectum, stomach, mammary glands, and prostate, which, as will be discussed below, might not fully regulate their cell volume during stimulated secretion. Notably, several of these epithelia are among the tissues in the body that are most commonly afflicted by cancer (Siegel et al., 2013). One of the most common mechanisms for initiating fluid secretion by agonists or hormones is opening of luminal $\mathrm{Cl}^{-}$channels and luminal and basolateral $\mathrm{K}^{+}$channels, and this also leads to a cell volume decrease. A number of transport mechanisms on the basolateral membrane are activated to provide ions for luminal exit and thus secretion, and this will potentially lead to regain of cell volume. Concurrently, the cells need to regulate their intracellular $\mathrm{pH}\left(\mathrm{pH}_{\mathrm{i}}\right)$, and for cells exhibiting net secretion of $\mathrm{H}^{+}$or $\mathrm{HCO}_{3}^{-}$(stomach, pancreatic ducts), this is a particular challenge. Figure $1 \mathbf{A}$ shows the basic model for ion transport across secretory cells such as pancreatic duct cell. As seen, this model includes a toolbox of ion channels and transporters (Novak et al., 2011; Frizzell and Hanrahan, 2012; Wilschanski and Novak, 2013), some of which are dys-regulated in cancer, as will be described below. The ion channels include: the cystic fibrosis transmembrane conductace regulator (CFTR) and $\mathrm{Ca}^{2+}$-activated $\mathrm{Cl}^{-}$channels (ANO1/TMEM16A), intermediate and large conductance $\mathrm{K}^{+}$ channels (IK-KCa3.1; BK-KCa1.1), volume sensitive KCNQ1 channels, and possibly voltage-regulated channels (HERGKv11.1; EAG2-Kv10.2) (Hayashi et al., 2012; Wang et al., 2013). The ion transporters include $\mathrm{Na}^{+}-\mathrm{K}^{+}-2 \mathrm{Cl}^{-}$cotransporters (NKCC1), $\mathrm{Na}^{+} / \mathrm{H}^{+}$exchangers (NHEs), $\mathrm{Cl}^{-} / \mathrm{HCO}_{3}^{-}$exchangers (SLC26A3,6 and SCL4A family), $\mathrm{Na}^{+}-\mathrm{HCO}_{3}^{-}$transporters (NBCs) and $\mathrm{H}^{+} / \mathrm{K}^{+}$-pumps. Another mechanism of achieving secretion, which is beyond the scope of this review, is that driven at least in part by exocytosis, such as in mammary epithelial cells secreting milk, or, for example, parietal cell secreting hydrochloric acid following exocytotic recruitment of the $\mathrm{H}^{+} / \mathrm{K}^{+}$pump from tubulovesicles to the apical membrane (Forte and Zhu, 2010).

In terms of cell volume, the crucial question is how ion/fluid transport on the two opposing membranes is coordinated. The main driving force for all these secondary- or tertiary- active processes is provided by the $\mathrm{Na}^{+} / \mathrm{K}^{+}$-ATPase. For secretory

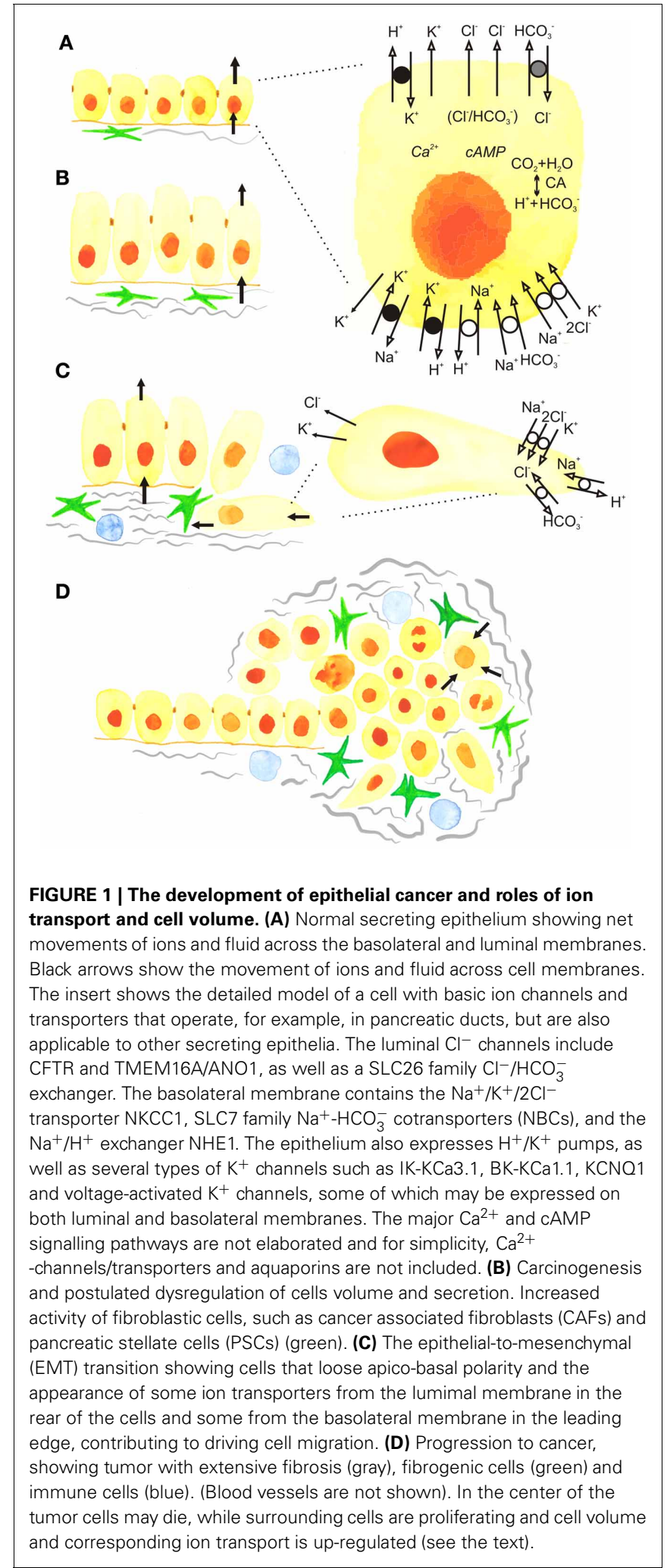

epithelia, the classical view is that basolateral transporters are activated secondarily to ion movements across the apical membrane due to alterations in electrochemical gradients or cell volume changes. Regarding the cell volume, known shrinkage-activated 
proteins are NHE1, NKCC1, and some Transient receptor potential vanniloid (TRPV) channels; and swelling activated proteins are volume regulated anion channels (VRAC), KCNQ1, twopore $\mathrm{K}^{+}$channels and $\mathrm{Ca}^{2+}$-activated $\mathrm{K}^{+}$channels (Hoffmann et al., 2009). In addition to these transporters and channels, other plasma membrane transporters are regulated by volumesensitive signaling pathways, including intracellular messengers, phosphorylation, and complex interactions involving cytoskeletal reorganization, $\mathrm{Ca}^{2+}$-signaling, and signaling via integrins and receptor tyrosine kinases (RTKs). For overview of these topics the reader is referred to the recent review (Pedersen et al., 2011). Here we just point out that recently discovered cell signaling pathways involving volume- and low $\mathrm{Cl}^{-}$-sensitive With No Lysine kinases (WNK), acting via Ste20-like kinases, SPS-related proline/alanine-rich kinase (SPAK) and oxidative stress responsive kinase (OSR1), may be key factors in secretory epithelia as they regulate NKCC1 and other transporters (Kahle et al., 2006; Hoffmann et al., 2009; McCormick and Ellison, 2011; Park et al., 2012). Similarly, autocrine and paracrine signaling via volume-sensitive ATP release and purinergic receptors may be important regulators of key short- and long-term cell volume and ion transport in epithelia and tumor models (Hug et al., 1994; Pedersen et al., 1999; Sørensen and Novak, 2001; Koltsova et al., 2011; see Novak, 2011). A number of ATP release mechanism have been proposed, including ion channels and transporters, and they utilize favorable electrochemical gradient (see Novak, 2011).

Nevertheless, in the acute/secretory state, the cell volume of many native epithelial cells recovers only partially or does not recover until the stimulus is withdrawn (Manabe et al., 2004; Bachmann et al., 2007). For example, some secretory cells shrink by more than $20 \%$ during stimulation and remain shrunken until the stimulus is withdrawn (Dissing et al., 1990; Foskett, 1990; Nakahari et al., 1990, 1991; Lee and Foskett, 2010) (Figure 1A). The chronic events of altered volume regulation and/or ion transporter expression might lead to pathological developments associated with cancer.

\section{LOSS OF EPITHELIAL POLARITY_IMPLICATIONS FOR ION TRANSPORT}

The polarized organization of ion transport proteins is essential for the normal function of epithelia, and appears to involve the interplay between the targeted delivery of transporters, restriction by cell-cell junctions, and the fact that the transporters reside in large protein-protein complexes linking them to the actin- and spectrin-based cytoskeleton (Nelson, 2009). During early stages of cancer development, the epithelial layer becomes disorganized, loses its cell-cell adhesions, and undergoes a dramatic change from apical-basal polarity to a mesenchymal cell type organization with a front-rear polarity (Figures 1B,C). This process is known as epithelial-to-mesenchymal transition (EMT), and has been well studied both for breast and pancreatic adenocarcinomas (Foroni et al., 2012; Rhim et al., 2012). Although the signaling mechanisms involved in EMT are far from fully elucidated and are partially context- and cell-type dependent, several central themes have been established. Upstream EMT features include up-regulation of transcription factors such as Slug,
Snail, and Twist. Markers of the full-blown EMT include upregulation of $\alpha$-smooth muscle actin ( $\alpha$-SMA), vimentin, and fibronectin, and down-regulation of epithelial markers such as E-cadherin, cytokeratins, and the tight junction protein $\mathrm{ZO}-1$ (Kalluri and Weinberg, 2009; Nelson, 2009; De Craene and Berx, 2013). Notably, although a number of factors involved in polarity switching are described (Nelson, 2009; Godde et al., 2010), essentially nothing is known regarding the roles and regulation of polarized transport proteins during EMT. Thus, it is an open question how the tightly compartmentalized localization of transport proteins gets "reinstructed" upon transition from apical-basal to a front-rear polarity (Figure 1C). The net result, however, is that at least some apical ion channels and transporters relocalize to the rear end, while several that are basolaterally located in epithelia move to the leading edge of the cell (compare Figures 1A,C). This specific reorganization of ion channels and transporters contributes importantly to cell migration (Schwab et al., 2012). Given the known roles of many of these transport proteins in cytoskeletal organization, signaling, and motility, we speculate that contributions to EMT might be added to the list of roles for dys-regulation of transport proteins in epithelial cancers.

\section{THE TUMOR MICROENVIRONMENT (TME)}

Tumors are highly complex tissues in which the cancer cells themselves are often the minority and co-exist with numerous other cell types in a physical/chemical microenvironment which differs dramatically from that of the normal tissue (Figure 1D). The tumor microenvironment (TME) undergoes extensive reciprocal interactions with the cancer cells and provides oncogenic signals that exacerbate cancer progression. The detailed properties of the TME have been excellently reviewed elsewhere (Mueller and Fusenig, 2004; Kalluri and Zeisberg, 2006; Pandol et al., 2009; Hanahan and Weinberg, 2011; Feig et al., 2012; Hanahan and Coussens, 2012). In the following, we set the stage for discussing the interrelationship of the TME with dys-regulated ion transport, focusing on PDAC and mammary adenocarcinoma.

\section{THE CELLULAR COMPONENT OF THE TME}

The predominant stromal cell type in many carcinomas, including breast cancers, is cancer associated fibroblasts (CAFs) (Kalluri and Zeisberg, 2006; Hanahan and Coussens, 2012). CAFs secrete extracellular matrix (ECM) components and matrix-degrading enzymes, and, being contractile, mechanically pull at the ECM, increasing its stiffness (Kalluri and Zeisberg, 2006; Hanahan and Coussens, 2012). CAFs also secrete numerous growth factors, cytokines and vascular endothelial growth factor (VEGF), stimulating tumor growth and, in general, angiogenesis (Kalluri and Zeisberg, 2006; Hanahan and Coussens, 2012), though paradoxically solid tumors show poor vascularization (see below). In PDAC, pancreatic stellate cells (PSCs) play a role similar to that of CAFs in breast cancer (Pandol et al., 2009; Feig et al., 2012), although CAFs per se are also present in PDAC (Scarlett, 2013). Quiescent PSCs are present in low numbers in the normal exocrine pancreas. PSCs become activated by exposure to factors secreted by the cancer cells, rendering them myofibroblast-like, 
highly proliferative, and motile (Pandol et al., 2009; Feig et al., 2012; Li et al., 2012). Excessive ECM deposition by PSCs is the main source of the marked desmoplasia in PDAC (Figure 1D). The PSCs also secrete growth factors, cytokines and chemokines, stimulating immune cell infiltration, angiogenesis, and cancer cell proliferation and motility (Pandol et al., 2009; Feig et al., 2012; Li et al., 2012). Infiltrating immune cells are of major importance in both mammary and pancreatic adenocarcinomas (Clark et al., 2007). Recruited tumor-associated macrophages release growth factors, chemokines, cytokines, and matrix-degrading enzymes, stimulating angiogenesis, cancer cell growth and invasiveness and further recruitment of pro-tumorigenic immune cells, while blocking activation of anti-tumorigenic $\mathrm{T}$ cells (Kalluri and Zeisberg, 2006; Pandol et al., 2009; Hanahan and Weinberg, 2011; Kees and Egeblad, 2011). Other central cellular stromal components are endothelial cells and pericytes (smooth-muscle-derived cells surrounding the endothelium). Finally, cancer stem cells or tumor-initiating cells have been found in the TME in both mammary and pancreatic cancer (Hermann et al., 2007; Iqbal et al., 2013).

\section{CHEMICAL/PHYSICAL PROPERTIES OF THE TME}

In addition to the wealth of cell types and secreted signaling factors mentioned above that sets the TME apart from the normal tissue, the TME also differs markedly from the normal tissue in its physical/chemical properties (see Harris, 2002; Heldin et al., 2004; Vaupel, 2004; Egeblad et al., 2010; Provenzano and Hingorani, 2013). Similar to the cellular component, the physical/chemical microenvironment exhibits distinct spatial heterogeneity throughout the tumor and develops dynamically as the cancer progresses. Because of the generally insufficient or collapsed tumor vasculature in many solid tumors, many areas of the TME are hypoxic or even anoxic (Harris, 2002). This has been shown directly for breast cancer (Vaupel, 2004), whereas evidence is more sparse for PDAC (see Feig et al., 2012). In conjunction with cancer-associated metabolic changes and high demand for energy and building blocks for anabolic reactions, this results in glucose deprivation, elevated lactate levels, and acidic extracellular $\mathrm{pH}\left(\mathrm{pH}_{\mathrm{e}}\right)$ (Heldin et al., 2004; Vaupel, 2004). Another consequence of the inefficient tumor vasculature and lymph outflow is elevated interstitial fluid pressure. A third physical characteristic of mammary and especially pancreatic cancers is that of desmoplasia-excessive accumulation and crosslinking of fibrillar collagens. This stiffens the ECM, in turn favoring cancer progression through effects on cell motility, differentiation, proliferation, and treatment response (Egeblad et al., 2010). In PDAC tumors, which are highly fibrotic and hypovascular, it is difficult for therapeutic agents to reach the tumor cells (Feig et al., 2012; Provenzano and Hingorani, 2013). Recent studies show that enzymatic targeting of stroma, ablation of the physical barrier improves vasculature and promotes drug delivery (Provenzano et al., 2012).

It seems likely that, in addition to selecting for hypoxia resistance and increased acid extrusion capacity (section Functional interactions between the TME and ion transport dys-regulation), the physically restricted TME with elevated interstitial pressure will tend to select for increased cell volume regulatory capacity due to the increased osmotic stress exposure. However, to our knowledge, this has never been directly studied. In addition, one might expect that physical constraints, hypoxia and necrosis will influence the concentration profiles of extracellular nucleosides/-tides within the tumor, in turn affecting a spectrum of tumor resident cells via purinergic signalling (Di Virgilio, 2012) (Figure 1D).

\section{FUNCTIONAL INTERACTIONS BETWEEN THE TME AND ION TRANSPORT dys-REGULATION}

While this has still been relatively little studied, it is clear that dys-regulation of ion transport in cancer is involved in important functional interactions with the TME. Firstly, the metabolic switch induced (in part) by hypoxia increases acid production in the cancer cells. This, in conjunction with hypoxia-induced elevation of hypoxia-inducible factor- $1 \alpha$ (HIF1 $\alpha$ ) levels increases the expression and/or activity of acid-extruding ion transport proteins and carbonic anhydrases (CAs). In breast cancer, these include the $\mathrm{Na}^{+} / \mathrm{H}^{+}$exchanger $\mathrm{NHE} 1$, the $\mathrm{Na}^{+}-\mathrm{HCO}_{3}^{-}$cotransporter NBCn1, monocarboxylate transporters MCT1 and MCT4, and CAIX (Bartosova et al., 2002; Lauritzen et al., 2010, 2012; Pinheiro et al., 2010; Boedtkjer et al., 2013; see Cardone et al., 2005) (Figure 2). In PDAC, evidence is much sparser, although neurotensin-induced NHE1 activation in PDAC cell lines is reported (Olszewski et al., 2010). Cytokines and growth factors secreted by the cancer cells and stromal cells likely also contribute to the up-regulation of ion transport. For instance, ErbB2

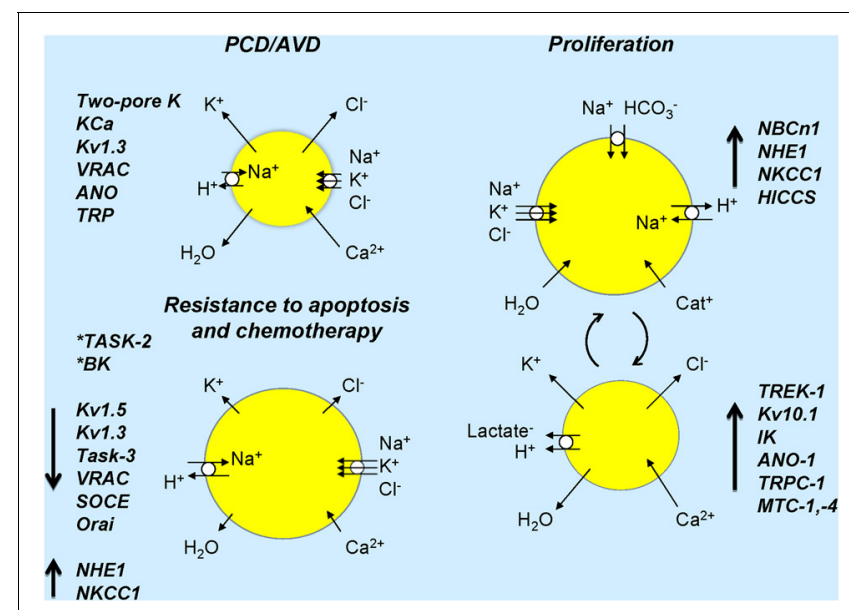

FIGURE 2 | lon channels and transporters and cell volume changes associated in normal and cancer cells. Cell sizes refer to expected cell volume changes and lengths of arrows on cells indicates up- or down-regulation or ion transporters/channels. Resistance to apoptosis is associated with down-regulation of several channels and inhibition of some channels (asterisks) induces resistance to apoptosis. In proliferation, several transporters and channels are up-regulated and over-expressed in cancer (see text). The right part of the figure shows ion transporters and channels that would lead to cell volume increase and those in the lower part indicate those that would lead to cell volume decrease. Large arrows next to named ion channels/transporters indicate their up- or down-regulation in cancer. Chronic activation of ion transport may lead to cell death. Dynamic activation or suppression of ion transport/cell volume with specific signals, in time or in given cells may lead to cancer development and progression. 
signaling increases NBCn1 expression and post-translationally activates NHE1 by phosphorylation in its C-terminal cytoplasmic domain (Lauritzen et al., 2010, 2012). In turn, ion transporters play major roles in creating the TME. Increased acid extrusion from the cancer cells can cause extracellular $\mathrm{pH}\left(\mathrm{pH}_{\mathrm{e}}\right)$ to become as low as 6.0 in some tumor regions (Vaupel, 2004). This favors further cancer development, e.g., through facilitating ECM degradation and cell motility, resistance to chemotherapy, and compromised anti-tumor function of cytotoxic T-cells and natural killer cells (Ward et al., 2013), while their role in maintaining $\mathrm{pH}_{\mathrm{i}}$ at or above the normal $\mathrm{pH}$ 7.0-7.4 favors metabolic, migratory, and proliferative activity and counteracts apoptotic death (Parks et al., 2011; Webb et al., 2011; Boedtkjer et al., 2012). Finally, it has been suggested that NHE1 may directly regulate ECM deposition by fibroblasts (Karydis et al., 2009).

\section{ROLES OF CELL VOLUME REGULATION IN CELL PROLIFERATION AND PROGRAMMED CELL DEATH (PCD)}

Importantly, cells do not have one preferred volume. Rather, the volume set point depends on the functional state of the cell and changes in cell volume serve as key physiological signals initiating downstream responses, such as transepithelial transport (see above), proliferation, migration and cell death (Figure 2) (see Hoffmann et al., 2009). Consequently, dysfunction of volumesensitive membrane transport proteins is associated with pathophysiological conditions related to control of these processes, including cancer.

\section{CELL PROLIFERATION}

Cell volume is a major factor in the regulation of cell cycle progression, with cell proliferation generally being inhibited by cell shrinkage and stimulated by cell swelling, respectively (Anbari and Schultz, 1993; Dubois and Rouzaire-Dubois, 2004; RouzaireDubois et al., 2005). Cell cycle progression depends on an increase in cell volume, and the capacity for regulatory volume decrease (RVD) changes during the cell cycle (see e.g., Hoffmann et al., 2009). Accordingly, cell volume was found to be greatest in the $\mathrm{M}$ phase and smallest in the G1 phase in CNE-2Z cells and to increase in parallel to the G1-S transition in fibroblasts (see Hoffmann et al., 2009) In Ehrlich Lettre ascites carcinoma (ELA) cells, significant water uptake and cell swelling occur in S phase (Klausen et al., 2010). The direct effects of changes in cell volume on the cell cycle control are still not clear, but it seems that RTKs and mitogen-activated protein kinases (MAPKs) play important roles. Accordingly, cell swelling induced by hyposmotic stress in general stimulates extracellular signal regulated kinase (ERK1/2), a major player in control of cell cycle progression (see e.g., Meloche and Pouyssegur, 2007; Hoffmann et al., 2009) and multiple Src family kinases are activated in response to cell swelling (Cohen, 2005). An interesting example, somewhat in contrast to the general picture given above, is described in glioma cells, where a marked premitotic cell shrinkage is necessary for the following cell division (Habela and Sontheimer, 2007).

Several types of ion channels have been implicated in the dysregulated control of cell cycle progression in cancer (Figure 2).
TRP channels. The resting level of $\left[\mathrm{Ca}^{2+}\right]_{\mathrm{i}}$ varies through the cell cycle (Schreiber, 2005). Thus, transient changes in $\left[\mathrm{Ca}^{2+}\right]_{i}$ occur at the exit from quiescence in early G1, at the G1/S phase transition and at the exit from $\mathrm{M}$ phase (Munaron, 2002; Munaron et al., 2004). In some cell types, TRPC1 is proposed to be involved in $\mathrm{Ca}^{2+}$ influx, RVD and cell cycle progression (Golovina et al., 2001; Salido et al., 2011; Madsen et al., 2012). A variety of $K^{+}$ channels have been implicated in the regulation of proliferation (Takahashi et al., 1993; Pei et al., 2003; Wang, 2004; Voloshyna et al., 2008) and cell cycle progression (Wang et al., 1998; Felipe et al., 2006). Accordingly, epithelial carcinomas often show high $\mathrm{K}^{+}$channel activity (Patel and Lazdunski, 2004; Wang, 2004; Felipe et al., 2006). Thus increased TREK-1 channel expression is associated with abnormal cell proliferation in prostate cancer cell lines and TREK-1 may be a novel molecular target in prostate cancer (Voloshyna et al., 2008). The $\mathrm{K}_{\mathrm{v}} 10.1$ (KCNH1) channel, which is widely studied in cancer, is important for cell cycle progression and is regulated through the cell cycle (Pardo et al., 2012). Thus, developing specific blockers for these channels in the treatment of cancer is a promising field (Felipe et al., 2006; Li and Xiong, 2011; Pardo et al., 2012). In PDAC, in addition to $\mathrm{K}_{\mathrm{v}} 10.1$ (Gomez-Varela et al., 2007), expression of $\mathrm{IK}$ (KCa3.1) is up-regulated in cancer tissue and some PDAC cell lines in which it contributes to stimulation of cell proliferation (Jager et al., 2004). $\mathrm{Cl}^{-}$channels are also involved in control of cell proliferation, and $\mathrm{Cl}^{-}$channel blockers inhibit cell proliferation (Voets et al., 1995; Pappas and Ritchie, 1998; Rouzaire-Dubois et al., 2000; Shen et al., 2000; Wondergem et al., 2001; Chen et al., 2007; Klausen et al., 2010) Several studies have found that VRAC currents differ in magnitude during the cell cycle (Shen et al., 2000; Doroshenko et al., 2001; Klausen et al., 2007, 2010). In nasopharyngeal carcinoma cells, VRAC activity was found to be central in control of passage through the G1 restriction point (Chen et al., 2007). The $\mathrm{Ca}^{2+}$-activated $\mathrm{Cl}^{-}$ channel TMEM16A (ANO-1) is overexpressed in many carcinomas, including human prostate carcinoma (Liu et al., 2012) and head and neck squamous cell carcinomas, where it induces stimulation of ERK1/2 and contributes to cell proliferation (Duvvuri et al., 2012). In mammary cancer, where TMEM16A (ANO-1) is also over-expressed and supports proliferation, it is linked to EGF receptor and calmodulin-dependent kinase II signaling (Britschgi et al., 2013). Thus, specific blockers of $\mathrm{Cl}^{-}$channels are also a potentially interesting field in the treatment of cancer (Duvvuri et al., 2012; Mazzone et al., 2012). Also several volumeregulatory transporters, including NHE1 (Putney and Barber, 2003) and NKCC1 (Panet et al., 2000) have been shown to exhibit cell-cycle dependent regulation and/or roles in regulation of cell proliferation, although the specific mechanisms are not fully elucidated and for NHE1 likely include effects both on $\mathrm{pH}_{\mathrm{i}}$ and cell volume.

In conclusion, ion channels and transporters have been implicated in the control of cell cycle checkpoints in normal as well as cancer cells, and specific types of ion channels seem to play an important role in tumor cell proliferation. However, a comprehensive mechanistic picture of the functional relation between ion channels and cell proliferation is yet not available (Becchetti, 2011). 


\section{PROGRAMMED CELL DEATH (PCD)}

A hallmark of PCD (or its more restrictive term, apoptosis) is a marked cell shrinkage (Kerr et al., 1972), which is entitled Apoptotic volume decrease, or AVD (Maeno et al., 2000) (Figure 2). AVD is an early event required for triggering of fullblown apoptosis (Maeno et al., 2000; Poulsen et al., 2010), and there is strong evidence that preventing cell volume regulation after shrinkage is associated with induction of apoptosis (Lang and Hoffmann, 2012). AVD results from a loss of $\mathrm{KCl}$ via $\mathrm{K}^{+}$ and $\mathrm{Cl}^{-}$channels, and concomitant loss of water (Bortner and Cidlowski, 1998; Okada and Maeno, 2001; Okada et al., 2001; Okada, 2004; Lang et al., 2007; Poulsen et al., 2010). Apoptosis thus depends on $\mathrm{K}^{+}, \mathrm{Cl}^{-}$and $\mathrm{Ca}^{2+}$ (to activate $\mathrm{Ca}^{2+}$ activated $\mathrm{K}^{+}$and $\mathrm{Cl}^{-}$channels) channels, such as, e.g., various voltage-dependent $\mathrm{K}^{+}$channels, two-pore $\mathrm{K}^{+}$channels, $\mathrm{Ca}^{2+}$ activated $\mathrm{K}^{+}$-channels, VRAC, some $\mathrm{Ca}^{2+}$-activated $\mathrm{Cl}^{-}$channels of the ANO family and some $\mathrm{Ca}^{2+}$ permeable TRP channels (see Lehen'kyi et al., 2011; Lang and Hoffmann, 2012). Enhanced expression of these ion channels in cancer cells will, as described above, typically stimulate proliferation and migration, but it will in general also be expected to be pro-apoptotic. It seems to be a paradox that cancer cells manage to up-regulate channels mainly involved in proliferation and migration, while at the same time avoiding the expected pro-apoptotic effect of these channels. We favor the interpretation that proliferation /cell cycle progression is dependent on specific windows of temporal-/spatial-/signalspecific modulation of $\mathrm{Cl}^{-}$and $\mathrm{K}^{+}$-channel activity, whereas apoptosis may be the result of a longer-term activation of $\mathrm{Cl}^{-}$and $\mathrm{K}^{+}$-channels (Figure 2). However, elucidation of this important question will require complete characterization of the cell-cycle dependent expression- and activity pattern of the specific channels involved and mapping of their precise subcellular localization.

Proapoptotic effects of enhanced $\mathrm{K}^{+}$channel expression include: (i) hyperpolarization and associated $\mathrm{Ca}^{2+}$ overload; (ii) AVD; and (iii) increased proteolytic cleavage of pro-caspase 3 secondary to the decrease in intracellular $\mathrm{K}^{+}$(Lehen'kyi et al., 2011). The proapoptotic effect of VRAC expression is predominantly on AVD (see e.g., Poulsen et al., 2010). The TRP channels are particularly involved in the control of $\mathrm{Ca}^{2+}$ influx participating in the PCD process (Lehen'kyi et al., 2011). Collectively, these findings strongly indicate that ion channel dys-regulation can underlie cancer cell resistance to apoptosis (see below). This is also the case for several ion transporters. Thus, during AVD, cells lose the capacity for counteracting cell shrinkage by triggering a regulatory volume increase (RVI) response (Maeno et al., 2006), which would be normally operating in a healthy cell. In fact, in HeLa cells undergoing apoptosis, the RVI mechanism seems to be weakened (Numata et al., 2008). The transporters involved in RVI thus tend to counteracts apoptosis. As the most important transport systems in RVI are NKCC1, NHE1, the $\mathrm{Na}^{+} / \mathrm{K}^{+}$ATPase, and in some cells also ENaC type cation channels (Hoffmann et al., 2009), it seems likely that increased expression or function of these in epithelial cancer would render tumor cells resistant to apoptosis, and in fact, this has been demonstrated in several types of cancers (see below).

\section{ION TRANSPORT AND DRUG RESISTANCE IN CANCER MULTI DRUG RESISTANCE (MDR)}

Chemotherapy resistance-cell-intrinsic or acquired-underlies the failure of most cancer treatments. Many factors are involved in resistance of cancer cells, such as decreased drug uptake, increased drug efflux, detoxification, increased DNA repair, and dys-regulation of apoptotic signaling (Krishna and Mayer, 2000; Stavrovskaya, 2000; Lothstein et al., 2001; Giacomini et al., 2010). One of the most important contributions to drug resistance in solid tumors such as PDAC is a failure to deliver drugs due to poor vascularization of the tumor and impermeability exhibited by dense desmoplasia (see section Chemical/physical properties of the TME for details). The current strategy is to overcome both physical barriers with multi-drug therapy approach (e.g., Provenzano et al., 2012).

ATP-binding cassette $(\mathrm{ABC})$ drug efflux pumps are widely studied in the context of chemotherapy resistance (see e.g., Litman et al., 2001) and will not be discussed here. As described above [sections Loss of epithelial polarity-implications for ion transport and Roles of cell volume regulation in cell proliferation and programmed cell death (PCD)], ion transporters play major roles in shaping the TME, which is, in turn, very important for drug delivery/chemotherapy resistance. The other major contribution of ion transporters in drug resistance in cancer is their role in the resistance to apoptosis, which is one of the major reasons for chemotherapy cross-resistance.

\section{RESISTANCE TO APOPTOSIS}

Resistance to apoptosis can develop when the AVD is prevented. This can be mediated by down-regulation of the $\mathrm{K}^{+}$and/or $\mathrm{Cl}^{-}$channels responsible for $\mathrm{AVD}$, as well as of $\mathrm{Ca}^{2+}$ channels involved in $\mathrm{Ca}^{2+}$ influx and hence modulation of $\mathrm{Ca}^{2+}$ sensitive apoptotic steps. Alternatively, resistant cell can develop an enhanced RVI response, which, as described above, counteracts AVD, by up-regulation of NHE1, NKCC1, or hypertonically induced cation channels (HICCS) (Figure 2). Accordingly, it was demonstrated that Chinese hamster ovary cells, which do not perform RVI because they lack of NHE1, are more prone to apoptosis compared to cells expressing NHE1 (Rotin and Grinstein, 1989). Moreover, in HeLa cells HICCS rescue cells from staurosporineelicited apoptosis (Numata et al., 2008). These studies underscore the critical role of volume regulation mechanisms in apoptotic resistance. Finally, although a detailed account of the roles of intracellular channels and transporters in PCD resistance is beyond the scope of this review, it may be noted that the mitochondrial voltage-dependent anion channel, VDAC-1, has been identified as a protein associated with resistance to cisplatin chemotherapy (Tajeddine et al., 2008) and has, although this remains controversial, been suggested to be part of the mitochondrial permeability transition pore, MPTP (see Javadov et al., 2011).

\section{THE ROLE OF ION CHANNELS IN CHEMOTHERAPY RESISTANCE}

Ion movements are important in the regulation of apoptosis, but exactly how they are involved in the development of chemotherapy resistance is not always clear; in Figure $\mathbf{2}$ and text below we summarize some molecular candidates. Decreased $\mathrm{K}^{+}$ 
permeability seems to be important cause of cancer cell resistance to apoptosis (Prevarskaya et al., 2010). For example, in PDAC, expression of Kv1.3 is down-regulated, presumably due to aberrant methylation of the Kv1.3 gene promoter, and it is postulated that this may render cells resistant to apoptosis (Brevet et al., 2009). Furthermore, the $\mathrm{K}^{+}$ionophore amphotericin B counteracts cisplatin resistance in cancer cell lines (Morikage et al., 1993; Beketic-Oreskovic and Osmak, 1995) by introduction of a high $\mathrm{K}^{+}$permeability, and Amphotericin B in conjunction with the NKCC blocker bumetanide was shown to augment cisplatininduced caspase 3 activation (Marklund et al., 2000, 2001, 2004). The TASK-2 $\mathrm{K}^{+}$channel blocker clofilium prevents AVD and abrogates cisplatin-induced caspase 3 activity in a cell line derived from mammary gland adenocarcinomas, Ehrlich ascites tumour cells (EATCs) (Poulsen et al., 2010). Targeting BK (KCa1.1) channels with teraethylammonium or iberiotoxin similarly attenuates cisplatin-induced apoptosis in spiral ligament fibrocytes of the cochlea (Liang et al., 2005). Several human cancers are characterized by a reduced expression of the redox-sensitive $\mathrm{K}^{+}$channel Kv1.5 (Bonnet et al., 2007) and down-regulation of Kv1.5 channels in human gastric cancer cells enhances resistance to apoptosis-inducing drugs such as cisplatin (Han et al., 2007). In PDAC, Kv1.3 is down-regulated (Brevet et al., 2009). In addition, TASK-3 (Kcnk9) has been shown to have oncogenic potential in several types of human carcinomas (Pei et al., 2003). Since $\mathrm{K}^{+}$ channels control cell membrane potential and thus $\mathrm{Ca}^{2+}$ influx, the effect of down-regulating $\mathrm{K}^{+}$channels on resistance to apoptosis can be also mediated by a decreased $\mathrm{Ca}^{2+}$ influx (see also below).

\section{Decreased $\mathrm{Cl}^{-}$permeability}

Induction of apoptosis involves activation of VRAC in several cell types (d'Anglemont de et al., 2004, 2008; Ise et al., 2005; Poulsen et al., 2010). Moreover, some studies have shown a decrease in $\mathrm{Cl}^{-}$permeability in various MDR cell models (Gollapudi et al., 1992; Lee et al., 2007; Poulsen et al., 2010; Min et al., 2011). The MDR-EATC and the KCP-4 human epidermoid cancer cells, which exhibit acquired resistance to cisplatin, both have strongly decreased VRAC activity (Lee et al., 2007; Poulsen et al., 2010). In KCP-4 cells it was further shown that restoration of the channel's functional expression leads to a decrease in the cisplatin resistance (Lee et al., 2007). Similar results were obtained in human lung adenocarcinoma cells (Min et al., 2011). In wild type EATC, cisplatin treatment induced an AVD response, whereas MDR-EATC showed almost no AVD response when treated with cisplatin (Poulsen et al., 2010). This indicates that impaired activity of VRAC channels contributes to the cisplatin resistance in MDR-EATC by preventing the necessary AVD process.

\section{$\mathrm{Ca}^{2+}$ influx}

The roles of $\mathrm{Ca}^{2+}$ transport in cancer and chemotherapy resistance have been excellently reviewed elsewhere (Prevarskaya et al., 2010, 2013; Dubois et al., 2013) and will only be briefly outlined here. As excessive $\mathrm{Ca}^{2+}$-influx contributes to PCD, conversely, preventing $\mathrm{Ca}^{2+}$ influx tends to help the cell to avoid PCD. In agreement with this, apoptosis-resistant prostate cancer cells have strongly reduced levels of store-operated calcium entry (SOCE) (Vanden Abeele et al., 2002; Vanoverberghe et al., 2004; Prevarskaya et al., 2013). The Orai protein is an important component of SOCE, thus down-regulation of Orai will protect the cancer cells from apoptosis. Accordingly, Orail was shown to contribute to the establishment of an apoptosisresistant phenotype in prostate cancer cells (Flourakis et al., 2010).

\section{pH-REGULATORY ION TRANSPORT PROTEINS IN DRUG RESISTANCE IN CANCER CELLS}

A growing body of evidence implicates $\mathrm{pH}$-regulatory ion transporters in drug resistance in cancer. The contributions of these transporters to resistance occurs at several levels. Firstly, the acidic extracellular environment in solid tumors, including the creation of a strongly acidic pericellular subdomain due to rapid $\mathrm{H}^{+}$efflux (Stock et al., 2007), will, all things equal, decrease the uptake by diffusion across the plasma membrane, of chemotherapeutic drugs which are weak bases, such as doxorubicine and vinblastine, and can alter the carrier-mediated uptake of drugs via $\mathrm{pH}$ sensitive uptake carriers (Tredan et al., 2007). Once the drug is inside the cell, the normal-to-alkaline $\mathrm{pH}_{\mathrm{i}}$, created in the tumor cytoplasm through rapid acid extrusion, impacts on the cell death machinery via multiple pathways (Pedersen, 2006). Most work in this context has been done on NHE1, inhibition or knockdown of which has been shown to enhance chemotherapeutically induced cell death in a number of cancer types (Reshkin et al., 2003; Rebillard et al., 2007; Lauritzen et al., 2010; Jin et al., 2011). Also proton pump inhibitors have been effectively used to combat chemotherapy resistance in some cancers (for a review, see De Milito and Fais, 2005), although the mechanisms are less clear, as the $\mathrm{H}^{+} \mathrm{V}$-ATPases generally predominantly localize to the endosomal/lysosomal compartments, and at least in some cancers appear to contribute little to cytosolic $\mathrm{pH}$ regulation (Lauritzen et al., 2010; Hulikova et al., 2013). Finally, inhibition of monocarboxylate carriers (MCTs) in cancer cells that strongly dependent on these transporters should also in principle sensitize cells to chemotherapy, however, little work has so far been done to address this directly (see Halestrap, 2013).

\section{SUMMARY AND PERSPECTIVES}

Epithelial cells are endowed with specific sets of ion channels and transporters that are organized in a polarized fashion specific for the function of the given epithelium. The molecular identities, regulation and roles of these channels and transporters in the physiology of epithelial transport and cell volume regulation are relatively well understood. Epithelial cells, no doubt due to their high proliferative rate, but perhaps also due to their continuously challenged cell volume regulation, walk a thin line between physiology and pathophysiology. We suggest, speculatively, that this may endow them with an inherently increased risk of undergoing key events contributing to development of carcinomas. It is interesting to note that in particular epithelia capable of secretion, such as prostate, mammary glands, colorectum, lung/bronchi, pancreas, stomach, and uterus seem to be frequent sites of cancer (Siegel et al., 2013). Does dys-regulation 
of existing ion channels/transporters, or changes in the expression of the channels lead to altered cell volume regulation and thus increased proliferation, resistance to apoptosis and chemotherapy? In this review, we have summarized existing evidence for dys-regulation of some of the important ion channels/transporters, generally from cell culture models. However, much more knowledge is needed on genuine epithelial cancer models as well as on epithelial cancers in vivo. The complex TME contains a number of local auto- and paracrine agents, and exhibits marked changes in $\mathrm{pH}$, oxygen levels, and probably ion concentrations, compared to the normal epithelial extracellular environment. Moreover, transformed epithelial cells frequently undergo EMT, the basal membrane is degraded, and the epithelial cells come into contact with cell

\section{REFERENCES}

Anbari, K., and Schultz, R. M. (1993). Effect of sodium and betaine in culture media on development and relative rates of protein synthesis in preimplantation mouse embryos in vitro. Mol. Reprod. Dev. 35, 24-28. doi: 10.1002/mrd.1080350105

Bachmann, O., Heinzmann, A., Mack, A., Manns, M. P., and Seidler, U. (2007). Mechanisms of secretionassociated shrinkage and volume recovery in cultured rabbit parietal cells. Am. J. Physiol. Gastrointest. Liver Physiol. 292, G711-G717. doi: 10.1152/ajpgi.00416.2006

Bachmann, O., Juric, M., Seidler, U., Manns, M. P., and Yu, H. (2011). Basolateral ion transporters involved in colonic epithelial electrolyte absorption, anion secretion and cellular homeostasis. Acta Physiol. (Oxf). 201, 33-46. doi: 10.1111/j.1748-1716.2010.02153.x

Bartosova, M., Parkkila, S., Pohlodek, K., Karttunen, T. J., Galbavy, S., Mucha, V., et al. (2002). Expression of carbonic anhydrase IX in breast is associated with malignant tissues and is related to overexpression of c-erbB2. J. Pathol. 197, 314-321. doi: 10.1002/path.1120

Becchetti, A. (2011). Ion channels and transporters in cancer. 1. Ion channels and cell proliferation in cancer. Am. J. Physiol. Cell Physiol. 301, C255-C265. doi: 10.1152/ajpcell.00047.2011

Beketic-Oreskovic, L., and Osmak, M. (1995). Modulation of resistance to cisplatin by amphotericin B and aphidicolin in human larynx carcinoma cells. Cancer Chemother. Pharmacol. 35, 327-333. doi: 10.1007/BF00689453

Boedtkjer, E., Bunch, L., and Pedersen, S. F. (2012). Physiology, pharmacology and pathophysiology of the $\mathrm{pH}$ regulatory transport proteins NHE1 and NBCn1: similarities, differences, and implications for cancer therapy. Curr. Pharm. Des. 18, 1345-1371. doi: 10.2174/138161212799504830

Boedtkjer, E., Moreira, J. M., Mele, M., Vahl, P., Wielenga, V. T., Christiansen, P. M., et al. (2013). Contribution of $\mathrm{Na}^{+}, \mathrm{HCO}_{3}^{-}$cotransport to cellular $\mathrm{pH}$ control in human breast cancer: a role for the breast cancer susceptibility locus NBCn1 (SLC4A7). Int. J. Cancer 132, 1288-1299. doi: 10.1002/ijc. 27782

Bonnet, S., Archer, S. L., AllalunisTurner, J., Haromy, A., Beaulieu, C., Thompson, R., et al. (2007). A mitochondria- $\mathrm{K}^{+}$channel axis is suppressed in cancer and its normalization promotes apoptosis and inhibits cancer growth. Cancer Cell 11, 37-51. doi: 10.1016/j.ccr.2006.10.020

Bortner, C. D., and Cidlowski, J. A. (1998). A necessary role for cell shrinkage in apoptosis. Biochem. Pharmacol. 56, 1549-1559. doi: 10.1016/S0006-2952(98)00225-1

Brevet, M., Fucks, D., Chatelain, D., Regimbeau, J. M., Delcenserie, R., Sevestre, H., et al. (2009). Deregulation of 2 potassium channels in pancreas adenocarcinomas: implication of KV1.3 gene promoter methylation. Pancreas 38, 649-654. doi: 10.1097/MPA.0b013e3181a56ebf

Britschgi, A., Bill, A., Brinkhaus, H., Rothwell, C., Clay, I., Duss, S., et al. (2013). Calcium-activated chloride channel ANO1 promotes breast cancer progression by activating EGFR and CAMK signaling. Proc. Natl. Acad. Sci. U.S.A. 110, E1026-1034. doi: 10.1073/pnas. 1217072110

Cardone, R. A., Casavola, V., and Reshkin, S. J. (2005). The role of disturbed $\mathrm{pH}$ dynamics and the $\mathrm{Na}^{+} / \mathrm{H}^{+}$exchanger in metastasis.

types they would not normally encounter. Future studies should map and functionally characterize the complete ion "transportomes" for the different cell types within the tumor, in order to uncover novel multi-therapeutic approaches to carcinoma chemotherapy.

\section{ACKNOWLEDGMENTS}

Work in the author's laboratories was supported by The Danish Council for Independent Research |Natural Sciences, The Danish Council for Independent Research |Health Sciences, The Lundbeck Foundation, The Novo Nordisk Foundation, The Carlsberg Foundation; and FP7 Marie Curie Initial Training Network "IonTraC" (Ion Transport Proteins in Control of Cancer Cell Behaviour).

Nat. Rev. Cancer 5, 786-795. doi: $10.1038 / \mathrm{nrc1713}$

Chen, L. X., Zhu, L. Y., Jacob, T. J., and Wang, L. W. (2007). Roles of volume-activated $\mathrm{Cl}$ - currents and regulatory volume decrease in the cell cycle and proliferation in nasopharyngeal carcinoma cells. Cell Prolif. 40, 253-267. doi: 10.1111/j.1365-2184.2007.00432.x

Clark, C. E., Hingorani, S. R., Mick, R., Combs, C., Tuveson, D. A., and Vonderheide, R. H. (2007). Dynamics of the immune reaction to pancreatic cancer from inception to invasion. Cancer Res. 67, 9518-9527. doi: 10.1158/00085472.CAN-07-0175

Cohen, D. M. (2005). SRC family kinases in cell volume regulation. Am. J. Physiol. Cell Physiol. 288, C483-C493. doi: 10.1152/ajpcell.00452.2004

d'Anglemont de, T. A., Berdeaux, A., Souktani, R., Henry, P., and Ghaleh, B. (2008). The volume-sensitive chloride channel inhibitors prevent both contractile dysfunction and apoptosis induced by doxorubicin through PI3kinase, Akt and Erk 1/2. Eur. J. Heart Fail. 10, 39-46. doi: 10.1016/j.ejheart.2007. 11.002

d'Anglemont de, T. A., Souktani, R., Henry, P., Ghaleh, B., and Berdeaux, A. (2004). Volume-sensitive chloride channels ( $\mathrm{ICl}$, vol) mediate doxorubicin-induced apoptosis through apoptotic volume decrease in cardiomyocytes. Fundam. Clin. Pharmacol. 18, 531-538. doi: 10.1111/j.1472-8206.2004.00273.x

De Craene, B., and Berx, G. (2013). Regulatory networks defining EMT during cancer initiation and progression. Nat. Rev. Cancer 13, 97-110. doi: 10.1038/nrc3447

De Milito, A., and Fais, S. (2005). Tumor acidity, chemoresistance and proton pump inhibitors.
Future. Oncol. 1, 779-786. doi: 10.2217/14796694.1.6.779

Dissing, S., Hansen, H. J., Undén, M., and Nauntofte, B. (1990). Inhibitory effects of amitriptyline on the stimulation-induced $\mathrm{Ca}^{2+}$ increase in parotid acini. Eur. J. Pharmacol. 177, 43-54. doi: 10.1016/0014-2999(90)90548-K

Di Virgilio, F. (2012). Purines, purinergic receptors, and cancer. Cancer Res. 72, 5441-5447. doi: 10.1158/0008-5472.CAN-12-1600

Doroshenko, P., Sabanov, V., and Doroshenko, N. (2001). Cell cycle-related changes in regulatory volume decrease and volumesensitive chloride conductance in mouse fibroblasts. J. Cell Physiol. 187, 65-72. doi: 10.1002/10974652(200104)187:1<65:AID-JCP10 $52>3.0 . \mathrm{CO} ; 2-\mathrm{A}$

Dubois, C., Vanden Abeele, F., and Prevarskaya, N. (2013). Targeting apoptosis by the remodelling of calcium-transporting proteins in cancerogenesis. FEBS J. doi: 10.1111/febs.12246. [Epub ahead of print].

Dubois, J. M., and Rouzaire-Dubois, B. (2004). The influence of cell volume changes on tumour cell proliferation. Eur. Biophys. J. 33, 227-232. doi: 10.1007/s00249-003-0364-1

Duvvuri, U., Shiwarski, D. J., Xiao, D., Bertrand, C., Huang, X., Edinger, R. S., et al. (2012). TMEM16A induces MAPK and contributes directly to tumorigenesis and cancer progression. Cancer Res. 72, 3270-3281. doi: 10.1158/0008-5472.CAN-120475-T

Egeblad, M., Rasch, M. G., and Weaver, V. M. (2010). Dynamic interplay between the collagen scaffold and tumor evolution. Curr. Opin. Cell Biol. 22, 697-706. doi: 10.1016/j.ceb.2010.08.015

Feig, C., Gopinathan, A., Neesse, A., Chan, D. S., Cook, N., and 
Tuveson, D. A. (2012). The pancreas cancer microenvironment. Clin. Cancer Res. 18, 4266-4276. doi: 10.1158/1078-0432.CCR-11-3114

Felipe, A., Vicente, R., Villalonga, N., Roura-Ferrer, M., MartinezMarmol, R., Sole, L., et al. (2006). Potassium channels: new targets in cancer therapy. Cancer Detect. Prev. 30, 375-385. doi: 10.1016/j.cdp.2006.06.002

Flourakis, M., Lehen'kyi, V., Beck, B., Raphael, M., Vandenberghe, M., Abeele, F. V., et al. (2010). Orail contributes to the establishment of an apoptosis-resistant phenotype in prostate cancer cells. Cell Death. Dis. 1:e75. doi: 10.1038/cddis.2010.52

Foroni, C., Broggini, M., Generali, D., and Damia, G. (2012). Epithelialmesenchymal transition and breast cancer: role, molecular mechanisms and clinical impact. Cancer Treat. Rev. 38, 689-697. doi: 10.1016/j.ctrv.2011.11.001

Forte, J. G., and Zhu, L. (2010). Apical recycling of the gastric parietal cell H, K-ATPase. Annu. Rev. Physiol. 72, 273-296. doi: 10.1146/annurevphysiol-021909-135744

Foskett, J. K. (1990). $\left[\mathrm{Ca}^{2+}\right]_{i}$ modulation of $\mathrm{Cl}^{-}$content controls cell volume in single salivary acinar cells during fluid secretion. Am. J. Physiol. 259, C998-C1004.

Frizzell, R. A., and Hanrahan, J. W. (2012). Physiology of epithelial chloride and fluid secretion. Cold Spring Harb. Perspect. Med. 2:a009563. doi: 10.1101/cshperspect.a009563

Giacomini, K. M., Huang, S. M., Tweedie, D. J., Benet, L. Z., Brouwer, K. L., Chu, X., et al. (2010). Membrane transporters in drug development. Nat. Rev. Drug Discov. 9, 215-236. doi: 10.1038/nrd3028

Godde, N. J., Galea, R. C., Elsum, I. A., and Humbert, P. O. (2010). Cell polarity in motion: redefining mammary tissue organization through EMT and cell polarity transitions. J. Mammary Gland Biol. Neoplasia. 15, 149-168. doi: 10.1007/s10911-010-9180-2

Gollapudi, S., McDonald, T., Gardner, P., Kang, N., and Gupta, S. (1992). Abnormal chloride conductance in multidrug resistant HL60/AR cells. Cancer Lett. 66, 83-89. doi: 10.1016/0304-3835(92) 90284-3

Golovina, V. A., Platoshyn, O., Bailey, C. L., Wang, J., Limsuwan, A., Sweeney, M., et al. (2001). Upregulated TRP and enhanced capacitative $\mathrm{Ca}^{2+}$ entry in human pulmonary artery myocytes during proliferation. Am. $J$.
Physiol. Heart Circ. Physiol. 280, H746-H755.

Gomez-Varela, D., Zwick-Wallasch, E., Knotgen, H., Sanchez, A., Hettmann, T., Ossipov, D., et al. (2007). Monoclonal antibody blockade of the human Eag1 potassium channel function exerts antitumor activity. Cancer Res. 67, 7343-7349. doi: 10.1158/0008-5472.CAN-07-0107

Habela, C. W., and Sontheimer, H. (2007). Cytoplasmic volume condensation is an integral part of mitosis. Cell Cycle 6, 1613-1620. doi: 10.4161/cc.6.13.4357

Halestrap, A. P. (2013). The SLC16 gene family-structure, role and regulation in health and disease. Mol. Aspects Med. 34, 337-349. doi: 10.1016/j.mam.2012. 05.003

Hanahan, D., and Coussens, L. M. (2012). Accessories to the crime: functions of cells recruited to the tumor microenvironment. Cancer Cell 21, 309-322. doi: 10.1016/j.ccr.2012.02.022

Hanahan, D., and Weinberg, R. A. (2011). Hallmarks of cancer: the next generation. Cell 144, 646-674. doi: 10.1016/j.cell.2011.02.013

Han, Y., Shi, Y., Han, Z., Sun, L., and Fan, D. (2007). Detection of potassium currents and regulation of multidrug resistance by potassium channels in human gastric cancer cells. Cell Biol. Int. 31, 741-747. doi: 10.1016/j.cellbi.2007.01.008

Harris, A. L. (2002). Hypoxia-a key regulatory factor in tumour growth. Nat. Rev. Cancer 2, 38-47. doi: $10.1038 /$ nrc704

Hayashi, M., Wang, J., Hede, S. E., and Novak, I. (2012). An intermediate-conductance $\mathrm{Ca}^{2+}$. activated $\mathrm{K}^{+}$channel is important for secretion in pancreatic duct cellsAn intermediate-conductance $\mathrm{Ca}^{2+}$-activated $\mathrm{K}^{+}$channel is important for secretion in pancreatic duct cells. Am. J. Physiol. Cell Physiol. 303, C151-C159. doi: 10.1152/ajpcell.00089.2012

Heldin, C. H., Rubin, K., Pietras, K., and Ostman, A. (2004). High interstitial fluid pressure-an obstacle in cancer therapy. Nat. Rev. Cancer 4 , 806-813. doi: $10.1038 /$ nrc1456

Hermann, P. C., Huber, S. L., Herrler, T., Aicher, A., Ellwart, J. W., Guba, M., et al. (2007). Distinct populations of cancer stem cells determine tumor growth and metastatic activity in human pancreatic cancer. Cell Stem Cell 1, 313-323. doi: 10.1016/j.stem.2007.06.002

Hoffmann, E. K., Lambert, I. H., and Pedersen, S. F. (2009). Physiology of cell volume regulation in vertebrates. Physiol. Rev. 89, 193-277. doi: 10.1152/physrev.00037.2007

Hug, M., Pahl, C., and Novak, I. (1994). Effect of ATP, carbachol and other agonists on intracellular calcium activity and membrane voltage of pancreatic ducts. Pflügers Arch. 426 412-418. doi: 10.1007/BF00388304.

Hulikova, A., Harris, A. L., VaughanJones, R. D., and Swietach, P. (2013) Regulation of intracellular $\mathrm{pH}$ in cancer cell lines under normoxia and hypoxia. J. Cell Physiol. 228, 743-752. doi: 10.1002/jcp.24221

Iqbal, J., Chong, P. Y., and Tan, P. H (2013). Breast cancer stem cells: an update. J. Clin. Pathol. 66, 485-490. doi: 10.1136/jclinpath-2012-201304

Ise, T., Shimizu, T., Lee, E. L., Inoue, H., Kohno, K., and Okada, Y. (2005) Roles of volume-sensitive Cl- channel in cisplatin-induced apoptosis in human epidermoid cancer cells. J. Membr. Biol. 205, 139-145. doi 10.1007/s00232-005-0779-y

Jager, H., Dreker, T., Buck, A., Giehl, K., Gress, T., and Grissmer, S. (2004). Blockage of intermediateconductance $\mathrm{Ca}^{2+}$-activated $\mathrm{K}^{+}$ channels inhibit human pancreatic cancer cell growth in vitro. Mol. Pharmacol. 65, 630-638. doi 10.1124/mol.65.3.630

Javadov, S., Hunter, J. C., BarretoTorres, G., and Parodi-Rullan, R. (2011). Targeting the mitochondrial permeability transition: cardiac ischemia-reperfusion versus carcinogenesis. Cell Physiol. Biochem. 27, 179-190. doi: 10.1159/000327943

Jin, W., Li, Q., Lin, Y., Lu, Y., Li, H., Wang, L., et al. (2011) Reversal of imatinib resistance in BCR-ABL-positive leukemia after inhibition of the $\mathrm{Na}^{+} / \mathrm{H}^{+}$ exchanger. Cancer Lett. 308, 81-90. doi: 10.1016/j.canlet.2011.04.016

Kahle, K. T., Rinehart, J., Ring, A., Gimenez, I., Gamba, G., Hebert, S. C., et al. (2006). WNK protein kinases modulate cellular $\mathrm{Cl}$ flux by altering the phosphorylation state of the $\mathrm{Na}-\mathrm{K}-\mathrm{Cl}$ and K-Cl cotransporters. Physiology (Bethesda) 21, 326-335. doi: 10.1152/physiol.00015.2006

Kalluri, R., and Weinberg, R. A (2009). The basics of epithelialmesenchymal transition. J. Clin. Invest. 119, 1420-1428. doi 10.1172/JCI39104

Kalluri, R., and Zeisberg, M. (2006). Fibroblasts in cancer. Nat. Rev. Cancer 6, 392-401. doi: $10.1038 / \mathrm{nrc1877}$

Karydis, A., Jimenez-Vidal, M., Denker, S. P., and Barber, D. L. (2009).
Mislocalized scaffolding by the $\mathrm{Na}-\mathrm{H}$ exchanger NHE1 dominantly inhibits fibronectin production and TGF-beta activation. Mol Biol. Cell 20, 2327-2336. doi: 10.1091/mbc.E08-08-0842

Kees, T., and Egeblad, M. (2011). Innate immune cells in breast cancerfrom villains to heroes. J. Mammary Gland Biol. Neoplasia. 16, 189-203. doi: 10.1007/s10911-011-9224-2

Kerr, J. F., Wyllie, A. H., and Currie, A. R. (1972). Apoptosis: a basic biological phenomenon with wideranging implications in tissue kinetics. Br. J. Cancer 26, 239-257. doi: 10.1038/bjc.1972.33

Klausen, T. K., Bergdahl, A., Hougaard, C., Christophersen, P., Pedersen, S. F., and Hoffmann, E. K. (2007). Cell cycle-dependent activity of the volume- and $\mathrm{Ca}^{2+}$-activated anion currents in Ehrlich lettre ascites cells. J. Cell. Physiol. 210, 831-842. doi: $10.1002 / j c p .20918$

Klausen, T. K., Preisler, S., Pedersen, S. F., and Hoffmann, E. K. (2010) Monovalent ions control proliferation of Ehrlich Lettre ascites cells. Am. J. Physiol. Cell Physiol. 299, C714-C725. doi: 10.1152/ajpcell.00445.2009

Koltsova, S. V., Platonova, A., Maksimov, G. V., Mongin, A. A., Grygorczyk, R., and Orlov, S. N. (2011). Activation of P2Y receptors causes strong and persistent shrinkage of C11-MDCK renal epithelial cells. Am. J. Physiol. Cell Physiol. 301, C403-C412. doi: 10.1152/ajpcell.00018.2011

Krishna, R., and Mayer, L. D. (2000). Multidrug resistance (MDR) in cancer. Mechanisms, reversal using modulators of MDR and the role of MDR modulators in influencing the pharmacokinetics of anticancer drugs. Eur. J. Pharm. Sci. 11, 265-283. doi: 10.1016/S0928-0987(00)00114-7

Lang, F. (2007). Mechanisms and significance of cell volume regulation. J. Am. Coll. Nutr. 26, 613S-623S. doi: 10.1080/07315724.2007.10719667

Lang, F., and Hoffmann, E. K. (2012). Role of ion transport in control of apoptotic cell death. Compr. Physiol. 2, 2037-2061. doi: 10.1002/cphy.c110046

Lang, F., Busch, G. L., Ritter, M., Volkl, H., Waldegger, S., Gulbins, E., et al. (1998). Functional significance of cell volume regulatory mechanisms. Physiol. Rev. 78, 247-306.

Lang, F., Foller, M., Lang, K., Lang P., Ritter, M., Vereninov, A., et al. (2007). Cell volume regulatory 
ion channels in cell proliferation and cell death. Methods Enzymol. 428, 209-225. doi: 10.1016/S0076-6879(07)28011-5

Lauritzen, G., Jensen, M. B., Boedtkjer, E., Dybboe, R., Aalkjaer, C., Nylandsted, J., et al. (2010). NBCn1 and NHE1 expression and activity in DeltaNErbB2 receptorexpressing MCF-7 breast cancer cells: contributions to $\mathrm{pHi}$ regulation and chemotherapy resistance. Exp. Cell Res. 316, 2538-2553. doi: 10.1016/j.yexcr.2010.06.005

Lauritzen, G., Stock, C. M., Lemaire, J., Lund, S. F., Jensen, M. F., Damsgaard, B., et al. (2012). The $\mathrm{Na}^{+} / \mathrm{H}^{+}$exchanger NHE1, but not the $\mathrm{Na}^{+}, \mathrm{HCO}_{3-}$ cotransporter NBCn1, regulates motility of MCF7 breast cancer cells expressing constitutively active ErbB2. Cancer Lett. 317, 172-183. doi: 10.1016/j.canlet.2011.11.023

Lee, E. L., Shimizu, T., Ise, T., Numata, T., Kohno, K., and Okada, Y. (2007). Impaired activity of volumesensitive Cl- channel is involved in cisplatin resistance of cancer cells. J. Cell. Physiol. 211, 513-521. doi: 10.1002/jcp.20961

Lee, R. J., and Foskett, J. K. (2010). Mechanisms of $\mathrm{Ca}^{2+}$-stimulated fluid secretion by porcine bronchial submucosal gland serous acinar cells. Am. J. Physiol. Lung Cell. Mol. Physiol. 298, L210-L231. doi: 10.1152/ajplung. 00342.2009

Lehen'kyi, V., Shapovalov, G., Skryma, R., and Prevarskaya, N. (2011). Ion channnels and transporters in cancer. 5. Ion channels in control of cancer and cell apoptosis. Am. J. Physiol. Cell Physiol. 301, C1281-C1289. doi: 10.1152/ajpcell.00249.2011

Li, M., and Xiong, Z. G. (2011). Ion channels as targets for cancer therapy. Int. J. Physiol. Pathophysiol. Pharmacol. 3, 156-166.

Li, X., Ma, Q., Xu, Q., Duan, W., Lei, J., and $\mathrm{Wu}$, E. (2012). Targeting the cancer-stroma interaction: a potential approach for pancreatic cancer treatment. Curr. Pharm. Des. 18, 2404-2415. doi: 10.2174/13816128112092404

Liang, F., Schulte, B. A., Qu, C., $\mathrm{Hu}, \mathrm{W}$., and Shen, Z. (2005). Inhibition of the calcium- and voltage-dependent big conductance potassium channel ameliorates cisplatin-induced apoptosis in spiral ligament fibrocytes of the cochlea. Neuroscience 135, 263-271. doi: 10.1016/j.neuroscience.2005.05.055

Litman, T., Druley, T. E., Stein, W. D., and Bates, S. E. (2001). From
MDR to MXR: new understanding of multidrug resistance systems, their properties and clinical significance. Cell. Mol. Life Sci. 58, 931-959. doi: 10.1007/PL00000912

Liu, W., Lu, M., Liu, B., Huang, Y., and Wang, K. (2012). Inhibition of $\mathrm{Ca}^{2+}$-activated $\mathrm{Cl}^{-}$channel ANO1/TMEM16A expression suppresses tumor growth and invasiveness in human prostate carcinoma. Cancer Lett. 326, 41-51. doi: 10.1016/j.canlet.2012.07.015

Lothstein, L., Israel, M., and Sweatman, T. W. (2001). Anthracycline drug targeting: cytoplasmic versus nuclear-a fork in the road. Drug Resist. Updat. 4, 169-177. doi: 10.1054/drup.2001.0201

Madsen, C. P., Klausen, T. K., Fabian, A., Hansen, B. J., Pedersen, S. F., and Hoffmann, E. K. (2012). On the role of TRPC1 in control of $\mathrm{Ca}^{2+}$ influx, cell volume, and cell cycle. Am. J. Physiol. Cell Physiol. 303, C625-C634. doi: 10.1152/ajpcell.00287.2011

Maeno, E., Ishizaki, Y., Kanaseki, T., Hazama, A., and Okada, Y. (2000). Normotonic cell shrinkage because of disordered volume regulation is an early prerequisite to apoptosis. Proc. Natl. Acad. Sci. U.S.A. 97, 9487-9492. doi: 10.1073/pnas.140216197

Maeno, E., Takahashi, N., and Okada, Y. (2006). Dysfunction of regulatory volume increase is a key component of apoptosis. FEBS Lett. 580, 6513-6517. doi: 10.1016/j.febslet.2006.10.074

Manabe, K., Shimizu, T., Morishima, S., and Okada, Y. (2004). Regulatory volume increase after secretory volume decrease in colonic epithelial cells under muscarinic stimulation. Pflugers Arch. 448, 596-604. doi: 10.1007/s00424-004-1301-6

Marklund, L., Andersson, B., BehnamMotlagh, P., Sandstrom, P. E., Henriksson, R., and Grankvist, K. (2004). Cellular potassium ion deprivation enhances apoptosis induced by cisplatin 16 . Basic Clin. Pharmacol. Toxicol. 94, 245-251. doi: 10.1111/j.17427843.2004.pto940508.x

Marklund, L., Henriksson, R., and Grankvist, K. (2000). Amphotericin B-induced apoptosis and cytotoxicity is prevented by the $\mathrm{Na}^{+}, \mathrm{K}^{+}, 2 \mathrm{Cl}^{-}$. cotransport blocker bumetanide. Life Sci. 66, L319-L324. doi: 10.1016/S0024-3205(00)00560-9

Marklund, L., Henriksson, R., and Grankvist, K. (2001). Cisplatininduced apoptosis of mesothelioma cells is affected by potassium ion flux modulator amphotericin B and bumetanide. Int. J. Cancer 93 , 577-583. doi: 10.1002/ijc.1363

Mazzone, A., Eisenman, S. T., Strege, P. R., Yao, Z., Ordog, T., Gibbons, S. J., et al. (2012). Inhibition of cell proliferation by a selective inhibitor of the $\mathrm{Ca}^{2+}$-activated $\mathrm{Cl}^{-}$ channel, Anol. Biochem. Biophys. Res. Commun. 427, 248-253. doi: 10.1016/j.bbrc.2012.09.022

McCormick, J. A., and Ellison, D. H. (2011). The WNKs: atypical protein kinases with pleiotropic actions. Physiol. Rev. 91, 177-219. doi: 10.1152/physrev.00017.2010

Meloche, S., and Pouyssegur, J. (2007). The ERK1/2 mitogen-activated protein kinase pathway as a master regulator of the G1- to S-phase transition. Oncogene 26, 3227-3239. doi: 10.1038/sj.onc.1210414

Min, X. J., Li, H., Hou, S. C., He, W., Liu, J., Hu, B., et al. (2011). Dysfunction of volume-sensitive chloride channels contributes to cisplatin resistance in human lung adenocarcinoma cells. Exp. Biol. Med. (Maywood) 236, 483-491. doi: 10.1258/ebm.2011.010297

Morikage, T., Ohmori, T., Nishio, K., Fujiwara, Y., Takeda, Y., and Saijo, N. (1993). Modulation of cisplatin sensitivity and accumulation by amphotericin B in cisplatinresistant human lung cancer cell lines. Cancer Res. 53, 3302-3307.

Mueller, M. M., and Fusenig, N. E. (2004). Friends or foes-bipolar effects of the tumour stroma in cancer. Nat. Rev. Cancer 4, 839-849. doi: 10.1038/nrc1477

Munaron, L. (2002). Calcium signalling and control of cell proliferation by tyrosine kinase receptors (review). Int. J. Mol. Med. 10, 671-676.

Munaron, L., Antoniotti, S., and Lovisolo, D. (2004). Intracellular calcium signals and control of cell proliferation: how many mechanisms. J. Cell. Mol. Med. 8, 161-168. doi: 10.1111/j.15824934.2004.tb00271.x

Nakahari, T., Murakami, M., Sasaki, Y., Kataoka, T., Imai, Y., Shiba, Y., et al. (1991). Dose effects of acetylcholine on the cell volume of rat mandibular salivary acini. Jpn. J. Physiol. 41, 153-168. doi: 10.2170/jjphysiol.41.153

Nakahari, T., Murakami, M., Yoshida, H., Miyamoto, M., Sohma, Y., and Imai, Y. (1990). Decrease in rat submandibular acinar cell volume during ACh stimulation. Am. J. Physiol. 258, G878-G886.

Nelson, W. J. (2009). Remodeling epithelial cell organization: transitions between front-rear and apical-basal polarity. Cold Spring Harb. Perspect. Biol. 1:a000513. doi: 10.1101/cshperspect.a000513

Novak, I. (2011). Purinergic signalling in epithelial ion transport-regulation of secretion and absorption. Acta Physiol. 202, 501-522. doi: 10.1111/j.1748-1716.2010.02225.x

Novak, I., Wang, J., Henriksen, K. L., Haanes, K. A., Krabbe, S., Nitschke, R., et al. (2011). Pancreatic bicarbonate secretion involves two proton pumps. J. Biol. Chem. 286, 280-289. doi: 10.1074/jbc.M110.136382

Numata, T., Sato, K., Okada, Y., and Wehner, F. (2008). Hypertonicityinduced cation channels rescue cells from staurosporine-elicited apoptosis. Apoptosis 13, 895-903. doi: $10.1007 / \mathrm{s} 10495-008-0220-\mathrm{y}$

Okada, Y. (2004). Ion channels and transporters involved in cell volume regulation and sensor mechanisms. Cell Biochem. Biophys. 41, 233-258. doi: 10.1385/CBB:41:2:233

Okada, Y., and Maeno, E. (2001). Apoptosis, cell volume regulation and volume-regulatory chloride channels. Comp. Biochem. Physiol. A Mol. Integr. Physiol. 130, 377-383. doi: 10.1016/S1095-6433(01)00424-X

Okada, Y., Maeno, E., Shimizu, T., Dezaki, K., Wang, J., and Morishima, S. (2001). Receptormediated control of regulatory volume decrease (RVD) and apoptotic volume decrease (AVD). J. Physiol. 532, 3-16. doi: 10.1111/j.1469-7793.2001.0003g.x

Olszewski, U., Hlozek, M., and Hamilton, G. (2010). Activation of $\mathrm{Na}^{+} / \mathrm{H}^{+}$exchanger 1 by neurotensin signaling in pancreatic cancer cell lines. Biochem. Biophys. Res. Commun. 393, 414-419. doi: 10.1016/j.bbrc.2010.02.009

Pandol, S., Edderkaoui, M., Gukovsky, I., Lugea, A., and Gukovskaya, A. (2009). Desmoplasia of pancreatic ductal adenocarcinoma. Clin. Gastroenterol. Hepatol. 7, S44-S47. doi: 10.1016/j.cgh.2009. 07.039

Panet, R., Marcus, M., and Atlan, H. (2000). Overexpression of the $\mathrm{Na}^{+} / \mathrm{K}^{+} / \mathrm{Cl}^{-}$cotransporter gene induces cell proliferation and phenotypic transformation in mouse fibroblasts. J. Cell. Physiol. 182, 109-118.

Pappas, C. A., and Ritchie, J. M. (1998). Effect of specific ion channel blockers on cultured Schwann cell proliferation. Glia 22, 113-120.

Pardo, L. A., Gomez-Varela, D., Major, F., Sansuk, K., Leurs, R., Downie, B. 
R., et al. (2012). Approaches targeting $\mathrm{K}(\mathrm{V}) 10.1$ open a novel window for cancer diagnosis and therapy. Curr. Med. Chem. 19, 675-682. doi: 10.2174/092986712798992011

Park, S., Hong, J. H., Ohana, E., and Muallem, S. (2012). The WNK/SPAK and IRBIT/PP1 pathways in epithelial fluid and electrolyte transport. Physiology (Bethesda) 27, 291-299. doi: 10.1152/physiol.00028.2012

Parks, S. K., Chiche, J., and Pouyssegur, J. (2011). pH control mechanisms of tumor survival and growth. J. Cell. Physiol. 226, 299-308. doi: 10.1002/jcp. 22400

Patel, A. J., and Lazdunski, M. (2004). The $2 \mathrm{P}$-domain $\mathrm{K}^{+}$channels: role in apoptosis and tumorigenesis. Pflugers Arch. 448, 261-273. doi: 10.1007/s00424-004-1255-8

Pedersen, S. F. (2006). The $\mathrm{Na}^{+} / \mathrm{H}^{+}$ exchanger NHE1 in stress-induced signal transduction: implications for cell proliferation and cell death. Pflugers Arch. 452, 249-259. doi: 10.1007/s00424-006-0044-y

Pedersen, S. F., Kapus, A., and Hoffmann, E. K. (2011). Osmosensory mechanisms in cellular and systemic volume regulation. J. Am. Soc. Nephrol. 22, 1587-1597. doi: 10.1681/ASN.2010121284

Pedersen, S., Pedersen, S. F., Nilius, B., Lambert, I. H., and Hoffmann, E. K. (1999). Mechanical stress induces release of ATP from Ehrlich ascites tumor cells. Biochim. Biophys. Acta 1416, 271-284. doi: 10.1016/S00052736(98)00228-4

Pei, L., Wiser, O., Slavin, A., Mu, D., Powers, S., Jan, L. Y., et al. (2003). Oncogenic potential of TASK3 (Kcnk9) depends on $\mathrm{K}^{+}$ channel function. Proc. Natl. Acad. Sci. U.S.A. 100, 7803-7807. doi: 10.1073/pnas. 1232448100

Pinheiro, C., Reis, R. M., Ricardo, S., Longatto-Filho, A., Schmitt, F., and Baltazar, F. (2010). Expression of monocarboxylate transporters 12 , and 4 in human tumours and their association with CD147 and CD44. J. Biomed. Biotechnol. 2010:427694. doi: 10.1155/2010/427694

Poulsen, K. A., Andersen, E. C., Hansen, C. F., Klausen, T. K., Hougaard, C., Lambert, I. H., et al. (2010). Deregulation of apoptotic volume decrease and ionic movements in multidrugresistant tumor cells: role of chloride channels. Am. J. Physiol. Cell Physiol. 298, C14-C25. doi: 10.1152/ajpcell.00654.2008

Prevarskaya, N., Skryma, R., and Shuba, Y. (2010). Ion channels and the hallmarks of cancer.
Trends Mol. Med. 16, 107-121. doi: 10.1016/j.molmed.2010.01.005

Prevarskaya, N., Skryma, R., and Shuba, Y. (2013). Targeting $\mathrm{Ca}^{2+}$ transport in cancer: close reality or long perspective. Expert. Opin. Ther. Targets 17, 225-241. doi: 10.1517/14728222. 2013.741594

Provenzano, P. P., Cuevas, C., Chang, A. E., Goel, V. K., Von Hoff, D. D., and Hingorani, S. R. (2012). Ezymatic targetting of the stroma ablates physical barriers to treatments of pancreatic ductal adenocarcinoma. Cancer Cell 21, 418-429. doi: 10.1016/j.ccr.2012.01.007

Provenzano, P. P., and Hingorani, S. R. (2013). Hyaluronan, fluid pressure, and stromal resistance in pancreas cancer. $\mathrm{Br}$. J. Cancer 108, 1-8. doi: 10.1038/bjc. 2012.569

Putney, L. K., and Barber, D. L. (2003). Na-H exchange-dependent increase in intracellular $\mathrm{pH}$ times G2/M entry and transition. J. Biol. Chem. 278, 44645-44649. doi: 10.1074/jbc.M308099200

Rebillard, A., Tekpli, X., Meurette, O., Sergent, O., LeMoigne-Muller, G., Vernhet, L., et al. (2007). Cisplatin-induced apoptosis involves membrane fluidification via inhibition of NHE1 in human colon cancer cells. Cancer Res. 67, 7865-7874. doi: 10.1158/00085472.CAN-07-0353

Reshkin, S. J., Bellizzi, A., Cardone, R. A., Tommasino, M., Casavola, V., and Paradiso, A. (2003). Paclitaxel induces apoptosis via protein kinase A- and p38 mitogen-activated protein-dependent inhibition of the $\mathrm{Na}^{+} / \mathrm{H}^{+}$exchanger (NHE) NHE isoform 1 in human breast cancer cells. Clin. Cancer Res. 9, 2366-2373.

Rhim, A. D., Mirek, E. T., Aiello, N. M., Maitra, A., Bailey, J. M., McAllister, F., et al. (2012). EMT and dissemination precede pancreatic tumor formation. Cell 148, 349-361. doi: 10.1016/j.cell.2011. 11.025

Rotin, D., and Grinstein, S. (1989). Impaired cell volume regulation in $\mathrm{Na}^{+}-\mathrm{H}^{+}$exchange-deficient mutants. Am. J. Physiol. 257(6 Pt 1), C1158-C1165.

Rouzaire-Dubois, B., Milandri, J. B., Bostel, S., and Dubois, J. M. (2000). Control of cell proliferation by cell volume alterations in rat $\mathrm{C} 6$ glioma cells. Pflugers Arch. 440, 881-888. doi: $10.1007 /$ s004240000371

Rouzaire-Dubois, B., O'Regan, S. and Dubois, J. M. (2005). Cell size-dependent and independent proliferation of rodent neuroblastoma $\mathrm{x}$ glioma cells. J. Cell. Physiol. 203, 243-250. doi: 10.1002/ jcp. 20240

Salido, G. M., Jardin, I., and Rosado, J. A. (2011). The TRPC ion channels: association with Orail and STIM1 proteins and participation in capacitative and non-capacitative calcium entry. Adv. Exp. Med. Biol. 704, 413-433. doi: 10.1007/978-94007-0265-3_23

Scarlett, C. J. (2013). Contribution of bone marrow derived cells to the pancreatic tumor microenvironment. Front. Physiol. 4:56. doi: 10.3389/fphys.2013.00056

Schreiber, R. (2005). $\mathrm{Ca}^{2+}$ signaling, intracellular $\mathrm{pH}$ and cell volume in cell proliferation. J. Membr. Biol. 205, 129-137. doi: 10.1007/s00232005-0778-z

Schultz, S. G., and Dubinsky, W. P. (2001). Sodium absorption, volume control and potassium channels: in tribute to a great biologist. J. Membr. Biol. 184, 255-261. doi: 10.1007/s00232-0010090-5

Schwab, A., Fabian, A., Hanley, P. J., and Stock, C. (2012). Role of ion channels and transporters in cell migration. Physiol. Rev. 92, 1865-1913. doi: 10.1152/physrev. 00018.2011

Shen, M. R., Droogmans, G., Eggermont, J., Voets, T., Ellory, J. C., and Nilius, B. (2000). Differential expression of volume-regulated anion channels during cell cycle progression of human cervical cancer cells. J. Physiol. 529 Pt 2, 385-394. doi: 10.1111/j.1469-7793. 2000.00385. $\mathrm{x}$

Siegel, R., Naishadham, D., and Jemal, A. (2013). Cancer statistics, 2013. CA Cancer J. Clin. 63, 11-30. doi: 10.3322/caac. 21166

Sørensen, C. E., and Novak, I. (2001) Visualization of ATP release in pancreatic acini in response to cholinergic stimulus. Use of fluorescent probes and confocal microscopy. J. Biol. Chem. 276, 32925-32932. doi: 10.1074/jbc. M103313200

Stavrovskaya, A. A. (2000). Cellular mechanisms of multidrug resistance of tumor cells. Biochemistry (Mosc). 65, 95-106.

Stock, C., Mueller, M., Kraehling, H., Mally, S., Noel, J., Eder, C., et al. (2007). pH nanoenvironment at the surface of single melanoma cells. Cell. Physiol. Biochem. 20, 679-686. doi: 10.1159/000107550

Tajeddine, N., Galluzzi, L., Kepp, O., Hangen, E., Morselli, E., Senovilla,
L., et al. (2008). Hierarchical involvement of Bak, VDAC1 and Bax in cisplatin-induced cell death. Oncogene 27, 4221-4323. doi: 10.1038/onc. 2008.63

Takahashi, A., Yamaguchi, H., and Miyamoto, H. (1993). Change in $\mathrm{K}+$ current of HeLa cells with progression of the cell cycle studied by patch-clamp technique. Am. J. Physiol. 265, C328-C336.

Tredan, O., Galmarini, C. M., Patel, K., and Tannock, I. F. (2007). Drug resistance and the solid tumor microenvironment. J. Natl. Cancer Inst. 99, 1441-1454. doi: 10.1093/jnci/djm 135

Vanden Abeele, F., Skryma, R., Shuba, Y., Van, C. F., Slomianny, C. Roudbaraki, M., et al. (2002). Bcl-2-dependent modulation of $\mathrm{Ca}^{2+}$ homeostasis and storeoperated channels in prostate cancer cells. Cancer Cell 1, 169-179. doi: 10.1016/S1535 6108(02)00034-X

Vanoverberghe, K., Vanden Abeele, F., Mariot, P., Lepage, G., Roudbaraki, M., Bonnal, J. L., et al. (2004). $\mathrm{Ca}^{2+}$ homeostasis and apoptotic resistance of neuroendocrinedifferentiated prostate cancer cells. Cell Death. Differ. 11, 321-330. doi: 10.1038/sj.cdd. 4401375

Vanoye, C. G., and Reuss, L. (1999). Stretch-activated single $\mathrm{K}^{+}$channels account for whole-cell currents elicited by swelling. Proc. Natl. Acad. Sci. U.S.A. 96, 6511-6516. doi: 10.1073/pnas.96.11.6511

Vaupel, P. (2004). Tumor microenvironmental physiology and its implications for radiation oncology. Semin. Radiat. Oncol. 14, 198-206. doi: 10.1016/j.semradonc. 2004.04.008

Voets, T., Szucs, G., Droogmans, G., and Nilius, B. (1995). Blockers of volume-activated $\mathrm{Cl}^{-}$currents inhibit endothelial cell proliferation. Pflugers Arch. 431, 132-134. doi: 10.1007/BF00374387

Voloshyna, I., Besana, A., Castillo, M., Matos, T., Weinstein, I. B., Mansukhani, M., et al. (2008). TREK-1 is a novel molecular target in prostate cancer. Cancer Res 68, 1197-1203. doi: 10.1158/00085472.CAN-07-5163

Wang, J., Haanes, K. A., and Novak, I. (2013). Purinergic regulation of CFTR and $\mathrm{Ca}^{2+}$-activated $\mathrm{Cl}^{-}$channels and $\mathrm{K}^{+}$channels in human pancreatic duct epithelium. Am. J. Physiol. Cell Physiol. 304, C673-C684. doi: 10.1152/ajpcell.00196.2012 
Wang, S., Melkoumian, Z., Woodfork, K. A., Cather, C., Davidson, A. G., Wonderlin, W. F., et al. (1998). Evidence for an early G1 ionic event necessary for cell cycle progression and survival in the MCF-7 human breast carcinoma cell line. J. Cell. Physiol. 176, 456-464.

Wang, Z. (2004). Roles of $\mathrm{K}^{+}$channels in regulating tumour cell proliferation and apoptosis. Pflugers Arch. 448, 274-286. doi: 10.1007/s00424004-1258-5

Ward, C., Langdon, S. P., Mullen, P., Harris, A. L., Harrison, D. J., Supuran, C. T., et al. (2013). New strategies for targeting the hypoxic tumour microenvironment in breast cancer. Cancer Treat. Rev. 39, 171-179. doi: 10.1016/j.ctrv. 2012.08.004

Webb, B. A., Chimenti, M., Jacobson, M. P., and Barber, D. L. (2011). Dysregulated $\mathrm{pH}$ : a perfect storm for cancer progression. Nat. Rev. Cancer 11, 671-677. doi: 10.1038/ nrc3110

Wilschanski, M., and Novak, I. (2013). The cystic fibrosis of exocrine pancreas. Cold Spring Harb. Perspect. Med. 3:a009746. doi: $10.1101 /$ cshperspect. a009746

Wondergem, R., Gong, W., Monen, S. H., Dooley, S. N., Gonce, J. L., Conner, T. D., et al. (2001). Blocking swelling-activated chloride current inhibits mouse liver cell proliferation. J. Physiol. 532, 661-672. doi: 10.1111/j.1469-7793. 2001.0661e.x

Conflict of Interest Statement: The authors declare that the research was conducted in the absence of any commercial or financial relationships that could be construed as a potential conflict of interest.

Received: 25 May 2013; accepted: 09 August 2013; published online: 30 August 2013.

Citation: Pedersen SF, Hoffmann EK and Novak I (2013) Cell volume regulation in epithelial physiology and cancer.
Front. Physiol. 4:233. doi: 10.3389/fphys. 2013.00233

This article was submitted to Membrane Physiology and Membrane Biophysics, a section of the journal Frontiers in Physiology.

Copyright (c) 2013 Pedersen, Hoffmann and Novak. This is an open-access article distributed under the terms of the Creative Commons Attribution License (CC BY). The use, distribution or reproduction in other forums is permitted, provided the original author(s) or licensor are credited and that the original publication in this journal is cited, in accordance with accepted academic practice. No use, distribution or reproduction is permitted which does not comply with these terms. 